\title{
Saanen keçilerinde çiftleşme sonrası progesteron ve gonadotropin uygulamaları ve gebelik oranlarının belirlenmesi
}

\author{
Mahmut İbiş ${ }^{1}$, Ali Reha Ağaoğlu \\ ${ }^{1}$ Sağlık Bilimleri Enstitüsü, Burdur Mehmet Akif Ersoy Üniversitesi, Burdur/Türkiye \\ ${ }^{2}$ Doğum ve Jinekoloji Anabilim Dalı, Burdur Mehmet Akif Ersoy Üniversitesi, Burdur/Türkiye
}

\section{Anahtar Kelimeler:}

anöstrus

gebelik oran

keçi

senkronizasyon

Key Words:

anestrus

goat

pregnancy rate

synchronization

Gelis Tarihi : 27.08 .202

Kabul Tarihi : 13.11.2021

Yayin Tarihi : 29.04.2022

Makale Kodu : 987935

Sorumlu Yazar:

AR. AĞAOGLUU

(rehaagaoglu@mehmetakif.edu.tr)

\section{ORCID}

M. İBISS : :0000-0003-3350-3184 AR. AĞ AOĞLU: 0000-0002-6545-8800

Bu çalışma Burdur Mehmet Akif Ersoy Üniversitesi Bilimsel Araștırmalar Koordinatörlüğü 0405YL16 numaralı proje ile desteklenmiştir.

\section{ÖZ}

Keçilerde, üreme mevsimi dışında yapılan senkronizasyon uygulamaları sonrasında karşılaşılan embriyonik kayıpların \% 70’i çiftleşme sonrası görülen luteal yetersizlikler nedeniyle şekillenmektedir. Bu çalışmanın amacı; luteal yetersizlikler nedeniyle oluşan embriyonik kayıpların önlenmesi için; anöstrus sezonunda çiftleşme sonrasında yapılan $\mathrm{GnRH}$ ya da progesteron uygulamalarının gebelik oranları üzerine etkilerinin araştırılmasıdır. Çalışmada herhangi infertilite sorunu bulunmayan ve anöstrus sezonunda bulunan toplam 30 baş Saanen keçisi kullanılmıştır. Keçiler rastgele 3 gruba ayrılmıştır. Tüm gruplarda progesteron içeren intravaginal araç $\left(\mathrm{CIDR}^{\circledR}\right)$ kullanılarak senkronizasyon programı uygulanmış ve teke katılmıştır. G1'de $(n=10)$ çiftleşmelerden sonra hiçbir uygulama yapılmamıştır. G2'de ( $n=10)$ keçilere son çiftleşmeden sonraki 12. gün buserelin enjeksiyonu yapılmıștır. G3'de (n=10) son çiftleşmeden sonraki 5. gün 5 gün süreyle CIDR $^{\circledR}$ uygulanmıştır. Çiftleşme sonrası tüm keçilerden 12. ve 30. günlerde kan örneği alınmış ve 30. gün gebelik muayeneleri yapılmıştır. Çalışma sonunda, gruplar arasında gebelik oranları açısından bir fark olușmadı̆̆ $(\mathrm{p}>0.05)$, her bir grupta alınan 12. ve 30. gün kan örneklerinde progesteron değerleri incelendiğinde; $\mathrm{G} 2$ hariç hiçbir grupta istatistiksel bir fark bulunmadığ1 belirlenmiştir. G2'de 30. gün ölçülen progesteron değerlerinin, G1 ve G3'de ölçülen değerlerden istatistiksel olarak farklı olduğu belirlenmiștir $(\mathrm{p}<0.01)$. Sonuç olarak çiftleşme sonrası yapılan buserelin veya intravaginal progesteron uygulamalarının gebelik oranları üzerine bir etkisinin olmadığı ancak; buserelin enjeksiyonlarının progesteron seviyelerini önemli derecede yükselttiği belirlenmiştir.

\section{Administration of progesterone and gonatotropin after breeding and determination of pregnancy rates in Saanen goats}

\begin{abstract}
Seventy percent of the embryonic losses after synchronization out of breeding season in goats are originated due to luteal insufficiency. The aim of this study was to investigate the effects of administrations of GnRH or progesterone after mating on pregnancy rates during anestrus season. A total of 30 heads of Saanen goats were used during the anestrus season, with no infertility problems. The goats are randomly divided into 3 groups. Synchronization program was applied by using intravaginal device containing progesterone $\left(\mathrm{CIDR}^{\circledR}\right)$ in all groups and mated in bucks. In $\mathrm{G} 1$ ( $\mathrm{n}=10$ ) no application was performed after mating. In G2 $(n=10)$ buserelin injections were made on the 12th day after the last mating. In $\mathrm{G} 3(\mathrm{n}=10), \mathrm{CIDR}^{\circledR}$ was applied for 5 days on 5 th day after last mating. Blood samples were taken at 12th and 30th days after mating from all goats and 30th day pregnancy examinations were performed. There was no difference between the groups in terms of pregnancy rates $(\mathrm{p}>0.05)$, when the progesterone values were examined in blood samples taken at 12th and 30th days in each group; no statistically significant difference was found in any group except G2. The progesterone values measured in G2 on the 30th day were statistically different from the values measured in G1 and G3 $(p<0.01)$. In conclusion, post mating buserelin or intravaginal progesterone administration has no effect on pregnancy rates; however buserelin injections have significantly increased progesterone levels.
\end{abstract}

\section{GİRİŞ}

Küçükbaş hayvan yetiştiriciliği yapılan işletmelerde uygulanan seksüel senkronizasyon yöntemleri işletmelerde üreme faaliyetlerinin ve suni tohumlamaların planlı bir şekilde yürütülmesine ve sürü bazında kısa sürede tamamlanmasına, planlanan zaman aralıklarında doğumların gerçekleştirilebilmesine olanak vermektedir. Ayrıca yapılan bu uygulamalar; yem kaynaklar1nın, barınakların ve iş gücünün daha verimli kullanılabilmesini sağlamaktadır. Bu bağlamda, uygulanan seksüel senkronizasyon protokolleri; işletmenin kuzu eti ve süt gibi ürünlerini piyasa fiyatlarının en uygun olduğu döneme göre planlayabilmesini sağlamaktadır (1). Süt üretimi yapan keçi işletmelerinin kârlılığ1; y1l boyunca piyasaya sunabilecek miktarda süt üretmelerine bağlıdır. Bu nedenle bu tip işletmelerde keçiler doğumdan hemen sonra mümkün olan en kısa sürede tekrar gebe kalmalıdır. Bu sürenin uzaması; yıllık olarak süt ve ŏ̆lak veriminin azalmasına neden olmaktadır. Bu konuda etkili 
olan en önemli sınırlayıcı neden, keçilerin mevsime bağlı seksüel aktivite göstermeleridir. Üreme mevsimi dişında yapılan seksüel senkronizasyon uygulamalarının başarısı ve sonrasında şekillenen gebelik oranlarının, üreme mevsimi içinde yapılan uygulamalarla karşılaştırıldığında oldukça düşük olduğu bildi- internal drug release, $\mathrm{CIDR}^{\circledR}$, Eazi-Breed, Zoetis, Türkiye), cloprostenol (Estrumate ${ }^{\circledR}$, MSD, Türkiye) ve eCG (Equine chorionic gonadotropin, Chronogest ${ }^{\circledR}$, MSD, Türkiye) kullan1larak konvensiyonel bir senkronizasyon programı uygulanmıştır (8) (Tablo 1).

Tablo 1. Progestagen temelli geleneksel senkronizasyon programı (8).

Table 1. Progestagen-based traditional estrus synchronization protocol (8).

\begin{tabular}{lcll}
\hline \multicolumn{1}{c}{ 0. gün } & \multicolumn{1}{c}{ 9. gün } & 11.gün & 12-13. günler \\
\hline $\begin{array}{l}\text { İntravaginal CIDR } \\
\text { uygulamas1 }\end{array}$ & $75 \mu \mathrm{g}$ cloprostenol, im & CIDR'in ç1kartılmas1, & Östrus gözlemi ve teke \\
& & 200 IU eCG, im & katımı \\
\hline
\end{tabular}

CIDR: Controlled internal drug release, $0.3 \mathrm{mg}$ progesteron içeren silikon intravaginal araç, Cloprostenol: PGF2 $\alpha$ analoğu, eCG: gebe kisrak koryonik gonadotropini

CIDR: Controlled internal drug release, silicone intravaginal device containing $0.3 \mathrm{mg}$ progesterone; cloprostenol: PGF $2 \alpha$ analog, eCG: equine chorionic gonadotrophin

rilmektedir (2). Bu konuda yapılan çalışmalarda; üreme mevsimi içinde yapılan seksüel senkronizasyon uygulamaları sonucunda Saanen keçilerinde \%84 (3), K1l keçilerinde \%85 (4) gibi yüksek gebelik oranları elde edilmiştir. Diğer taraftan, üreme mevsimi dışında yapılan uygulamalarda Saanen keçilerinde elde edilen gebelik oranlarının \%40’lara düștüğü belirlenmiștir (10). İvesi koyunlarında yapılan benzer bir çalışmada da üreme mevsimi dışında yapılan uygulamalarda gebelik oranlarının \%58.3 olduğu ortaya konulmuştur (5).

Üreme mevsimi dışında yapılan seksüel senkronizasyon uygulamaları sonrasında oluşan gebelik oranlarının düşük olmasının nedenlerinden biri embriyonik ölümlerdir. Embriyonik ölümlerin \%70’i aşım ya da suni tohumlamadan sonraki ilk 16 gün içerisinde gerçekleşmekte ve daha çok luteal yetersizliklere bağlı şekillenmektedir (6). Keçilerde gebeliğin devamı için gerekli olan progesteron hormonunun tek kaynağı korpus luteumdur. Bu nedenle herhangi bir nedenle korpus luteumun prematüre regrese olması ya da işlevinin kısa bir süre aksaması erken embriyonik ölümler ya da abortuslar ile sonuçlanabilmektedir $(2,7)$.

Luteal yetersizlikler nedeniyle şekillenen embriyonik ölümlerin önlenmesi düşüncesiyle yapılan bu çalışmada, üreme mevsimi dişında progestagen temelli seksüel senkronizasyon yöntemleri kullanılarak östrusları senkronize edilen keçilerde, aşım sonrasında korpus luteumu desteklemek amaciyla gonadotropin veya progestagen uygulamalarının oluşan gebelik oranları üzerine etkilerinin araştırılması amaçlanmıştır.

\section{GEREÇ ve YÖNTEM}

\section{Hayvan materyali ve klinik uygulamalar}

Sunulan çalışma Burdur Mehmet Akif Ersoy Üniversitesi, Hayvan Deneyleri Yerel Etik Kurulu tarafindan 28/180 numaralı kararı ile onay almıştır. Çalışmada; Burdur ilinde yetiştirilen, doğumlarının üzerinden en az 2 ay geçmiş, daha önce en az bir doğum yapmış üreme sezonu dişında bulunan toplam 30 baş Saanen keçisi kullanılmıştır.

Çalışmaya dâhil edilen keçiler 3 gruba ayrılmıştır. Tüm keçilere $0.3 \mathrm{mg}$ progesteron içeren intravaginal araç (Controlled
Senkronizaston programı tamamlandiktan sonra her grup farklı bir bölmeye alınmıştır. Daha sonra her grubun içine daha önceden fertil olduğu belirlenmiş olan birer adet teke katılmıştır. Tekeler keçiler aşımı reddedene ve östrus belirtileri kaybolana kadar grubun içinde tutulmuştur.

Grup 1 (G1, n=10): Bu grupta yer alan keçilere seksüel senkronizasyon uygulaması sonrasında hiçbir uygulama yapılmamıs, teke katılmış ve aşımlar kaydedilmiştir.

Grup 2 (G2, n=10): Bu grupta yer alan keçilere seksüel senkronizasyon uygulaması sonrasında teke katılmış ve aşımlar kaydedilmiştir. Her bir keçiye son aşımdan sonraki 12. gün bir gonadotropin salg1latıc1 hormon $(\mathrm{GnRH})$ analoğu olan buserelin (Receptal ${ }^{\circledR}$, MSD, Türkiye) $0.004 \mathrm{mg}$ dozda kas içi yol ile uygulanmiştır.

Grup 3 (G3, n=10): Bu grupta yer alan keçilere seksüel senkronizasyon uygulaması sonrasında teke katılmış ve aşımlar kaydedilmiştir. Her bir keçiye son aşımdan sonraki 5. gün, daha önceki senkronizasyon uygulamasında kullanılmış olan intravaginal araçlar $\left(\mathrm{CIDR}^{\circledR}\right)$ tekrar 5 gün süreyle uygulanmıştır.

Tüm keçilerde aşım sonrası 30. günde transrektal ultrasonografik yöntem ile yapılan gebelik muayeneleri yapılmiştır. (6.5 MHz, lineer prob, KAI XIN KX5500, Çin).

\section{Laboratuvar analizleri}

Tüm keçilerden aşım sonras1 12. ve 30. günlerde progesteron analizleri için steril kan alma tüplerine $v$. jugularis'ten kan alınmıştır. Alınan kan örnekleri soğuk zincir koșullarında laboratuvara götürülerek santrifüj edilmiş ve çıkartılan serumlar kapaklı plastik tüplerde $-20^{\circ} \mathrm{C}$ 'de saklanmıştır. Toplanan tüm serum örnekleri soğuk zincir koşullarına uyarak uluslararası akreditasyon belgesine sahip (TÜRKAK TS EN ISO/IEC 17025) özel bir laboratuvara gönderilmiş (Düzen Norwest Laboratuvar1, Ankara) ve ECLIA (Electrochemiluminescence immunoassay analyser) yöntemi ile progesteron analizleri yaptırılmıştır.

\section{Gebelike muayeneleri}

Tüm keçilerin gebelik muayeneleri aşım sonrası 30. günde 
transrektal ultrasonografi ile yapılmıstır. Belirlenen gebelikler kaydedilmiş ve gebelik oranlanı hesaplanmıştır.

\section{Istatistiksel analizler}

Çalışma sonunda ortalama ve standart sapma verileri hesaplanmıştır (X土SS). Elde edilen verilerin gruplar arası karşılaştırılmasında ki-kare testi kullanılmıștır. Tüm hesaplamalar SPSS v.14 paket programı kullanılarak yapılmıştır.

\section{BULGULAR}

\section{Klinik bulgular}

Çalışmada izlenen tüm keçiler CIDR $^{\circledR}$ çıkartılmasını izleyen 24-36 saat içerisinde östrus göstermişler ve çiftleştirilmişlerdir.
Tablo 2. Gruplara göre gebelik oranları.

Table 2. Pregnancy rates by the groups.

\begin{tabular}{lc}
\hline Gruplar & Gebelik oranı \\
& $\mathbf{( x / n )}$ \\
\hline Grup I $(n=10)$ & $7 / 10$ \\
Grup II $(n=10)$ & $6 / 10$ \\
Grup III $(n=10)$ & $5 / 10$ \\
\hline
\end{tabular}

\section{Gebelik bulgular}

G1'de 7, G2'de 6 ve G3'te 5 olmak üzere toplam 18 keçinin gebe olduğu belirlenmiştir (Tablo 2) (Şekil 1). Gruplar gebelik oranları açısından karşılaştırıldığında istatistiksel olarak herhangi bir fark belirlenmemiştir ( $\mathrm{p}>0.05)$. Yapılan tüm uygu-

Tablo 3. Kan serumu progesteron değerleri (ng/ml).

Table 3. Blood serum progesterone levels ( $\mathrm{ng} / \mathrm{ml}$ ).

\begin{tabular}{lcc}
\hline \multirow{2}{*}{ Gruplar } & \multicolumn{2}{c}{ Serum progesteron değerleri $(\mathbf{X} \pm \mathbf{S S})$} \\
\cline { 2 - 3 } & 12. gün & 30. gün \\
\hline Grup 1 & $8.56 \pm 4.01$ & $7.83 \pm 3.17$ \\
Grup 2 & $5.85 \pm 2.62$ & $22.44 \pm 8.27$ \\
Grup 3 & $9.40 \pm 1.79$ & $8.53 \pm 2.97$ \\
\hline \hline
\end{tabular}

X: ortalama; SS: standart sapma

$\mathrm{X}$ : mean; SD: standart deviation

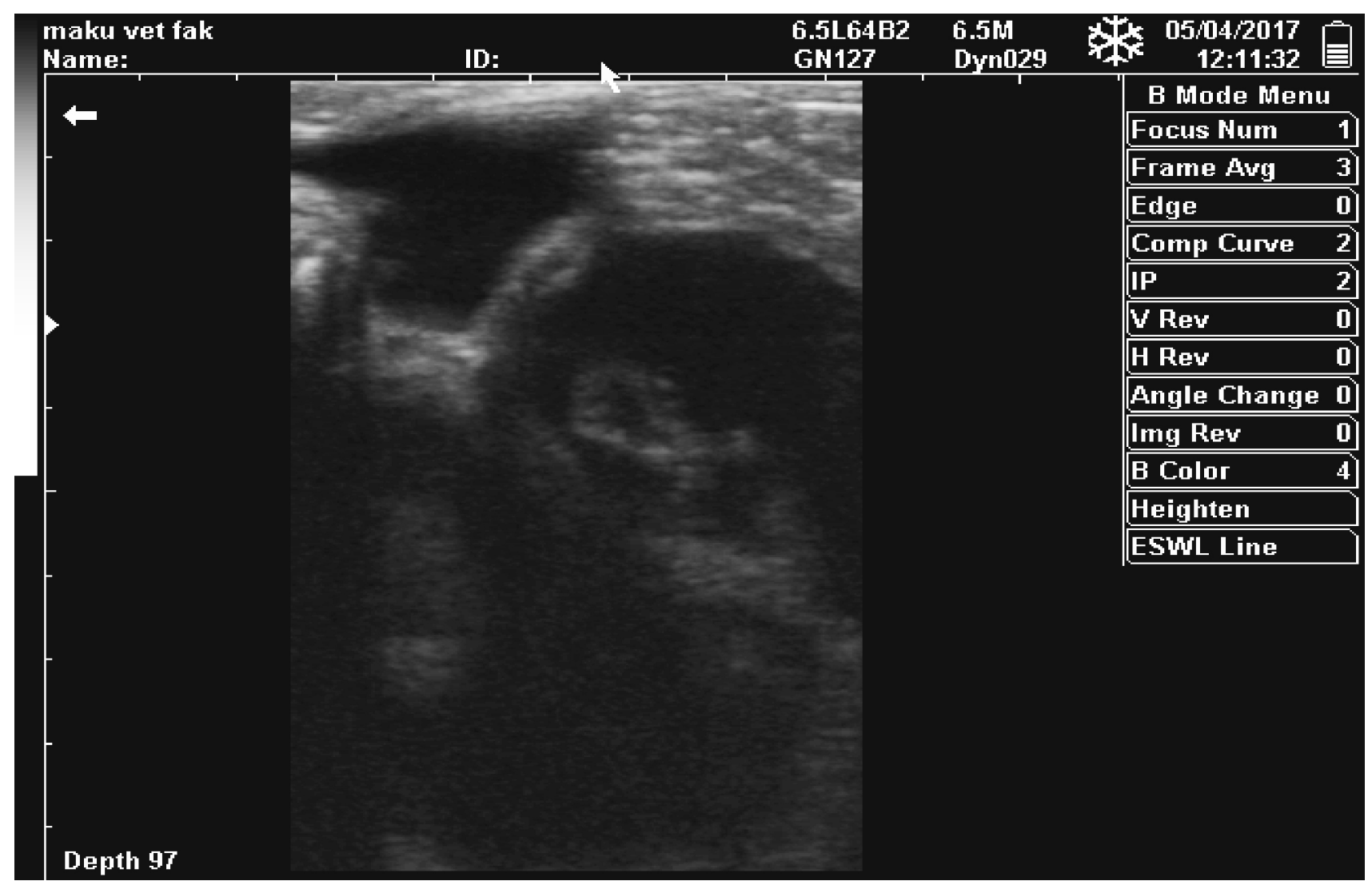

Şekil 1. Çiftleşme sonrası 30. günde ultrasonografik olarak gebeliklerin belirlenmesi.

Figure 1. Diagnosis of pregnancies ultrasonographically on the 30th day after mating. 


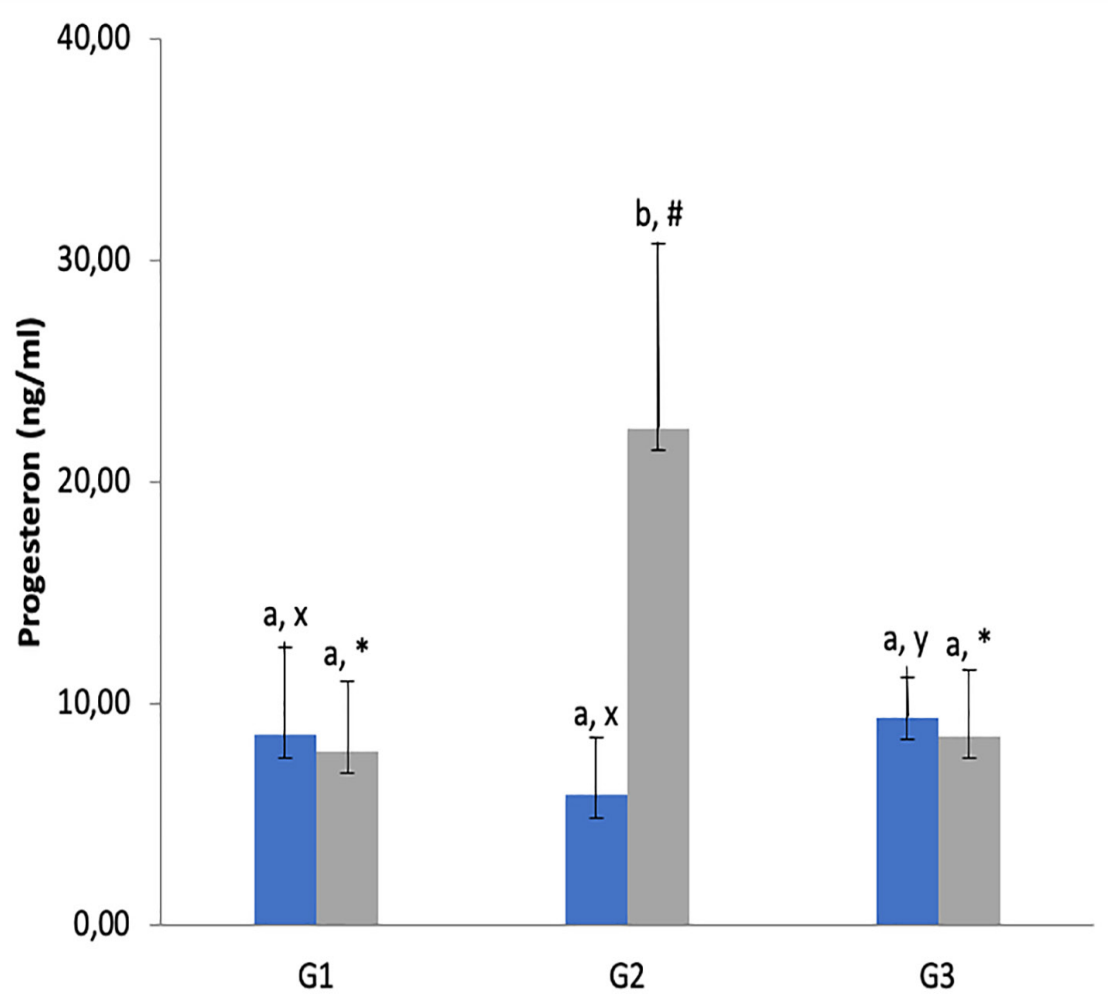

Şekil 2. Gruplara göre progesteron düzeyleri. Gruplar içinde 12 ile 30. günler arasında yapılan ölçümler için, a:b, p<0.05; Gruplar arasında 12. günler arasında yapılan ölçümler için, x:y, $\mathrm{p}<0.05$; gruplar arasinda 30. günler arasında yapilan ölçümler için, *:\#, p<0.01.

Figure 2. Blood serum progesterone levels by the groups. For measurements done between 12 and 30 days within groups, a:b, $\mathrm{p}<0.05$; for measurements done between groups on the 12th day, $\mathrm{x}: \mathrm{y}$, $\mathrm{p}<0.05$; for measurements done between groups on the 30 th day, $*: \#, \mathrm{p}<0.01$.

lamalar sonunda tüm gruplar birlikte değerlendirildiğinde elde edilen toplam gebelik oranı $\% 63.33$ olarak hesaplanmıştır.

\section{Laboratuvar bulgular}

Tüm çalışma gruplarında, aşım sonrası 12. ve 30. günlerde serum progesteron seviyeleri Tablo 3'de verilmiştir/sunulmuştur.

Yapılan değerlendirmede yalnızca gebelik şekillenmiş olan keçilerden alınan kan örnekleri kullanılmıștır. Calıșma gruplarında aşımdan 12 ve 30 gün sonra alınan kan örneklerinde progesteron seviyeleri karşılaştırıldığında, sadece G2'de 12 ve 30. günlerde alınan örnekler arasında istatistiksel bir fark belirlenmiştir $(p<0.05)$. Diğer gruplarda ise bir fark bulunmamıştır. Alınan örnekler gruplar arasında karşılaştırıldığında; așım sonrası 12. günde alınan örneklerde G3 ile G2 arasında bir fark oluştuğu belirlenmiştir $(\mathrm{p}<0.05)$. Otuzuncu gün alınan örnekler karşılaştırıldığında ise; G2'de ölçülen progesteron değerlerinin (22.44 \pm 8.27) G1 ve G3'de ölçülen progesteron değerlerinden (sirasiyla 7.83 $\pm 3.17,8.53 \pm 2.97$ ) istatistiksel olarak farklı olduğu belirlenmiştir $(\mathrm{p}<0.01)$ (Şekil 2).

\section{TARTIŞMA}

Keçilerde üreme mevsiminde yapılan seksüel senkronizasyon uygulamaları ile karşılaştırıldığında, üreme sezonu dışında yapılan uygulamalar sonucunda elde edilen gebelik oranları oldukça düşük olmaktadır. Üreme mevsimi dışında yapılan uygulamalar sonucunda şekillenen düşük gebelik oranları genellikle uygun olmayan çevre koşulları ve güneş 1şığ̣ sürelerinin uzun olması gibi nedenlere bağlı şekillenmektedir. Keçilerde üreme sezonu dışında gebelik oranlarının düşük olmasinın diğer bir neden ise korpus luteumun erken regresyonuna ya da yeterli miktarda progesteron salgilayamamasina bağlı şekillenen embriyonik ölümlerdir (9).

Konu ile ilgili olarak yapılan araștırmalarda keçilerde konvansiyonel yöntem kullanılarak üreme mevsimi dışında yapılan seksüel senkronizasyon uygulamalarında farklı östrus ve gebelik oranları elde edilmiştir. Örneğin Saanen ve Alpin keçilerinde üreme mevsimi dışında yapilan bir çalışmada 12 gün flurogeston asetat (FGA) uygulanmış daha sonra takip eden 10. günde $500 \mathrm{IU}$ eCG ve $50 \mathrm{mcg}$ cloprostenol enjeksiyonu yapilmıștır. Çalışma sonunda tüm keçiler östrus göstermiş ancak gebelik oranının \%69.1 olduğu bildirilmiştir (10). İtalya'da yetiştirilen yerel ırklar üzerinde üreme mevsimi dışında yapılan bir araştırmada ise ise; keçilere 5 gün FGA içeren intravaginal sünger uygulanmış, süngerin uzaklaştırıldığı gün $300 \mathrm{IU}$ eCG ve 50 mcg cloprostenol uygulanmıştır. Çalışma sonunda \% $\% 6.4$ östrus belirlenirken, gebelik oranlar1 \%63.4 belirlenmiștir (11). Üreme mevsimi dışında Saanen keçilerinde yapılan bu çalışma sonunda da konvansiyonel senkronizasyon program uygulanan keçilerin (G1) tamamının östrus gösterdiği belirlenmiştir. Östrus gösteren ve aşım yaptırlan keçilerde ise gebelik ise $7 / 10$ olarak belirlenmiştir. Bu sonucun konuyla ilgili yapılan diğer çalışmalar ile karşılaştırıldığında benzerlik gösterdiği belirlenmiştir.

Koyun ve keçilerde implantasyon öncesi erken gebelik dö- 
neminde progesteron desteği sağlamanın yalnızca gebelik oranlarını arttırmadığ1 aynı zamanda fötal gelişimi de olumlu yönde etkilediği bildirilmektedir $(12,13,14)$. Aşım sonrası yaklaşık 12. günde uygulanan gonadotropinlerin blastosist gelişimini uyardığı ve embriyonik kaynaklı bir sitokin olan interferon-tau (IFN-t) salınımının arttı̆̆1 (15) ve luteal hücrelerin stabilitesinin arttırtığ1 belirlenmiştir (16). Bu bağlamda İngiltere'de yetiştirilen bir koyun 1rk1 olan Welsh Halfbred 1rk1 koyunlarda yap1lan bir araştırmada, uygulanan konvansiyonel senkronizasyon programı uygulanmıştır. Senkronizasyon sonrasında östrus gösteren ve aşım yaptırılan koyunlara aşım sonrası 12. günde bir gonadotropin analoğu olan buserelin enjeksiyonu yapılmıştır. Çalışma sonunda, buserelin yapılmayan kontrol grubunda $15 / 20$, buserelin yapilan grupta ise $14 / 20$ oranlarında gebelik belirlenmiştir (17). Benzer şekilde Saanen 1rkı keçilerde yapılan bir araştırmada da gebelik oranları üzerine buserelin'in etkisini araştırılmıştır. Çalışmada Saanen keçilerine 12 gün süre ile $3 \mathrm{mg}$ norgestomet içeren deri altı implant uygulanmış ve implantın çıkarılmasindan hemen sonra 500 IU eCG ve $75 \mu$ g cloprostenol uygulanmıştır. Çalışmada keçilerin bir grubuna tohumlamadan hemen sonra $4 \mu \mathrm{g}$ buserelin asetat diğer bir grubuna tohumlamadan hemen sonra ve tohumlamadan 12 gün sonra 4 $\mu \mathrm{g}$ buserelin uygulanmıştır. Çalışma sonucunda sadece seksüel senkronizasyon uygulanan kontrol grubunda $\% 68.42$; buserelin uygulanan gruplarda ise sirasiyla; $\% 52.63$ ve $\% 47.37$ oranında gebelik belirlenmiştir (3). Yapılan bu araştırmada da benzer şekilde; çiftleşme sonras1 12. günde buserelin uygulanan grup (G2) ile kontrol grubu (G1) karşılaştırıldığında gebelik oranları açısından bir fark olmadı̆̆ belirlenmiştir.

Koyun ve keçilerde aşım sonrası progesteron desteği sağlayabilmek için yapılan uygulamalardan bir diğeri tekrar progestagen içeren araçların kullanılmasıdır. Konu ile ilgili olarak keçilerde yapılan bir araştırmada, 14 gün süre ile medroksiprogesteron asetat (MAP) içeren intravaginal sünger uygulanmış ve süngerin uzaklaştırıldığı gün 500 IU eCG uygulanmıştır. Aşım sonras1 5. gün bir gruba tekrar MAP içeren süngerler 14 gün süreyle uygulanmıştır. Aşım sonrası progestagen desteği yap1lan bu grupta gebelik oranının \%44.4 olduğu belirlenmiş ve kontrol grubuna göre istatistiksel olarak bir fark oluşmad1ğ1 bildirilmiştir (18). Koyunlarda yapılan başka bir çalışmada; aşım sonras1 5-26. günlerde intravaginal MAP içeren sünger uygulaması yapılmıştır. Kontrol grubu ile karşılaştırıldığında MAP uygulanan grupta gebelik oranlarının ve serum progesteron seviyelerinin istatistiksel olarak bir farklılık oluşturmadı̆̆1 belirlenmiştir (4). Bu araştırmada da gebelik oranları karşılaşt1rıldığında, G3 ile G1 arasında herhangi bir fark oluşmamıştır. Serum progesteron seviyeleri açısından ise; aşım sonrası 12. günde alınan kan örnekleri gruplar arasında karşılaştırıldığında G3 ile G2 arasında istatistiksel bir fark oluştuğu belirlenmiştir. Henüz hiçbir eksojen hormon uygulamasının yapılmadığ1 bu dönemde böyle bir farkın oluşmasının tesadüfi olabileceği, bireysel farklılıkların bu farkın oluşmasında rol oynayabileceği düşünülmüştür. Gruplar içinde 12. gün ve 30. gün alınan kan örnekleri karşılaştırıldığında; sadece G2'de bir fark oluştuğu belirlenmiştir. Ayrıca aşım sonrası 30. gün alınan kan örnekleri gruplar arasında karşılaştırıldığında G2'de alınan örneğin istatistiksel olarak diğer gruplardan yüksek olduğu belirlenmiştir. Bu durum ile ilgili olarak; koyun ve keçilerde aşım sonrası yapılan GnRH uygulamalarının serum progesteron seviyeleri üzerine etkilerinin araştırıldığı çalışmalarda $(15,17,19)$ progesteron seviyelerinin, GnRH uygulamas1 yapilmayan kontrol gruplarına göre daha yüksek olduğu bildirilmektedir. Progesteron seviyesinde görülen bu yükselmenin, GnRH'nın luteinleştirici hormon salınımını uyarması ve bu hormonun luteotropik uyarımı sonucu oluştuğu düşünülmektedir $(20,21)$. Yapılan bu çalışmada da benzer şekilde çiftleşme sonrası buserelin uygulanan grupta serum progesteron seviyelerinin yüksek olduğu ortaya konulmuştur.

\section{SONUÇ}

Sonuç olarak yapılan araştırmada, üreme mevsimi dışında bulunan Saanen keçilerine progestagen temelli konvansiyonel yöntem ile seksüel senkronizasyon uygulaması yapılmış ve bu uygulamalar sonrasında aşım yapan keçilere GnRH veya intravaginal progesteron uygulamaları yapılarak gebelik oranları üzerine bir etkisinin olup olmadığı araştırılmıştır. Çalışma sonucunda bu çalışma düzeni ve bu hayvan sayısı ile herhangi bir fark oluşturmadığ1 belirlenmiştir. Konuya ilişkin olarak daha fazla sayıda hayvanın kullanıldığı araştırmalar yapılarak bu oranların tekrar ortaya konulmasının hayvan yetiştiriciliği aç1sında faydalı olacağı düşünülmüştür. Diğger taraftan çiftleşme sonrası 12. günde buserelin uygulaması yapılan keçilerde serum progesteron seviyelerinin diğer gruplarda bulunan keçilere göre yüksek olması bu dönemde bulunan keçilerde embriyonik ve fötal gelişimi olumlu yönde etkileyebilme potansiyeline sahiptir $(43,61,71)$. Bu bağlamda elde edilen veriler 1şı̆̆ında, ileride yapılacak olan çalışmalarda çiftleşme sonrası GnRH analoğu uygulamalarının yavru doğum ağırlıkları üzerine etkisinin araştırılmasının yerinde olacağı kanaatine varılmıştır.

\section{BEYANNAMELER}

\section{Etik Onayı}

Bu çalışma Burdur Mehmet Akif Ersoy Üniversitesi Hayvan Deneyleri Yerel Etik Kurulu'nun 09.03.2016 tarihli toplantısında 180 karar sayısı ile etik onayı almıştır.

\section{Çıkar Çatışması}

Yazarlar arasında herhangi bir çıkar çatışması yoktur.

\section{Yazar Katkıları}

Fikir, Kavram ve Tasarım: A.R.A

Veri Toplama ve Analiz: A.R.A, M.I

Makalenin Yazımı: A.R.A, M.İ

Eleştirel İnceleme: A.R.A

\section{Veri kullanılabilirliği}

Bu çalışmanın bulgularını destekleyen veriler makul talep üzerine sorumlu yazardan temin edilebilir.

\section{KAYNAKLAR}

1. Whitley NC, Jacson DJ. An update on estrus synchronization in goats: A minor species. J Anim Sci. 2004; 82: 270-276.

2. Alaçam E. Üremenin kontrolü. (Ed.): Alaçam E. Evcil Hayvanlarda Doğum ve İnfertilite (5.Bask1), Medisan, Ankara, 2005; s: 71-80.

3. Ince D, Köker A. The effect of estrus synchronization on the reproductive chracateristics of Turkish Saanen goats 
and growth characteristics of kids under extensive conditions. African J Agri Res. 2011; 6(26): 5715-5719.

4. Cinar M, Ceyhan A, Yilmaz O, Erdem H (2017): Effect of estrus synchronization protocols including PGF2a and GnRH on fertility parameters in hair goats during breeding season. J Anim Plant Sci. 2017; 27(4): 1083-1087.

5. Özyurtlu N, Ay SS, Küçükaslan İ, Güngör Ö, Aslan S. Effect of subsequent two short-term, short-term and longterm progestagen treatment on fertility of Awassi ewes out of the breeding season. Ankara Univ Vet Fak Derg. 2011; 58: 105-109.

6. Özyurtlu N, Bademkıran S. Koyunlarda ÖstrusSenkronizasyonu ve Östrusu Uyarma Yöntemleri. Dicle Üniv Vet Fak Derg. 2010; 1(1): 17-22.

7. Uslu BA, Gülyüz F. Erken Anöstrus Döneminde Renkli Tiftik Keçilerinde Intravaginal Sünger, CIDR-G ve Kulak İmplantı Uygulamalarını Takiben GnRH Enjeksiyonunun Fertilite Üzerine Etkisi. Kafkas Univ Vet Fak Derg. 2009; 15 (3): 385-390.

8. Baldassarre H, Karatzas CN. Advanced assisted reproduction Technologies (ART) in goats. Anim Reprod Sci. 2004; 82-83:255-266.

9. Özer MÖ, Doğruer G. Aşım sezonunda Şami keçilerinde progestagen içeren deri altı implant ve vaginal süngerlerin uzun ve kısa süreli uygulamalarının fertilite üzerine etkisi. Kafkas Üniv Vet Fak Derg. 2011; 17: 47-52.

10. Leboeuf B, Forgerit Y, Bernelas D, Pougnard JL, Senty E, Driancourt MA. Efficacy of two types of vaginal sponges to control onset of oestrus, time of preovulatory LH peak and kidding rate in goats inseminated with variable numbers of spermatozoa. Theriogenology, 2003; 60: 1371-1378.

11. Martemucci G, D’Alessandro AG. Induction/synchronization of oestrus And

ovulation in dairy goats with different short term treatments and fixed time intrauterine or exocervical insemination system. Anim Reprod Sci. 2011; 126: 187194.

12. Garrett JE, Geisert RD, Zavy MT, Morgan GL. Evidence for maternal regulation of early conceptus growth and development in beef cattle. J Reprod Fertil. 1988; 84: 437-446.

13. Kleemann DO, Walker SK, Seamark RF. Enhanced fetal growth in sheep administered progesterone during the Srst three days of pregnancy. J. Reprod Fertil. 1994; 102: 411-417.

14. Mcmillan KL, Day AM, Taufa VK, Gibb M, Pearce MG. Effects of an agonist of gonadotrophin releasing hormone in cattle 1 . Hormone concentrations and cycle length. Anim Reprod Sci. 1985; 8: 203-212

15. Nephew KP, Cardenas H, McClure KE, Ott TL, Bazer FW, Pope WF. Effects of administration of human chorionic gonadotropin or progesterone before maternal recognition of pregnancy on blastocyst development and pregnancy in sheep. J Anim Sci. 1994; 72: 453-458.
16. Fonseca JF, Silva Filho JM, Pinto Neto A, Palhares MS, Ruas JRM, Alvin MTT, BelissaÅL rio H, Saliba WP. Plasma progesterone concentration in recipient heifers submitted to administration of rbST, GnRH or hCG on day five of the estrous cycle Arq Bras Med Vet Zootec. 2001; 53(4): 451- 458.

17. Khan TH, Beck NFG, Khalid M. The effects of GnRH analouge (buserelin) or hCG (chorulon) on day 12 of pregnancy on ovarian function, plasma hormone concentrations, conceptus growth and placentation in ewes and ewe lambs. Anim Reprod Sci. 2007; 102(3-4): 247-257.

18. Nava-Trujillo H, Chango-Villasmil J, Finol-Parra G, Maldonado-Suarez J, Torres-Rodriguez P, Carrillo-Fernandez F, Gil-Huerta L, Gonzales N. Brief communication: effect of post-mating progestagen administration on pregnancy rate in crossbreed goats following an induced estrus. Revista Cientifica. 2008; 18(5): 578-581.

19. McCracken JA, Custer EE, Lamsa JC. Luteolysis; A Neuroendocrine Med Lated Event. Physiol Rev. 1999; 79: 263-324.

20. Farin CE, Moeller CL, Mayan H, Gamboni F, Sawyer $\mathrm{HR}$, Niswender GD. Effect of luteinizing hormone and human chorionic gonadotropin on cell populations in the ovine corpus luteum. Biol Reprod. 1988; 38: 413-421.

21. Fitz TA, Mayan MH, Sawyer HR, Niswender GD. Characterisation of two steroidogenic cell types in the ovine corpus luteum. Biol Reprod. 1982; 27: 703-711. 
